\title{
The Great War and Dutch Contract Law: Resistance, Responsiveness and Neutrality
}

\author{
Willem H van Boom
}

This is the pre-peer reviewed version of the following article

"The Great War and Dutch Contract Law: Resistance, Responsiveness and Neutrality"

which has been published in final form at (2014) 2(2) Comparative Legal History 303-324

\begin{abstract}
Throughout the Great War, the Netherlands tried frantically to remain a neutral nation between the warring Central Powers and the Entente Forces. Notwithstanding its neutrality, the war left distinct marks on Dutch society and economy. This article argues that it also left marks, both temporary and lasting, on Dutch contract law. Never since the introduction of the Dutch Civil Code in 1838 had the Netherlands been exposed to such a disruptive international conflict as the Great War. Therefore, the war presented the first systemic test of Civil Code doctrines such as impossibility and force majeure. As far as these doctrines are concerned, some have argued that the Great War was no different from other, less disruptive economic events. However, on closer inspection one may find that the application of private law doctrines under war conditions seemed to reflect the Dutch neutrality doctrine. The courts strictly construed and enforced contracts, mostly rejected defences involving 'impossibility' and vis maior, and often held that contracting parties had knowingly assumed the risks associated with contracting during a war. Moreover, the Great War marked the end of nineteenth-century laissez-faire notions in regulatory policies, which in turn caused a gradual shift in balance between public law and freedom of contract. In hindsight, the War can also be regarded as the turning point in Dutch doctrinal thinking on the respective roles of and the relationship between force majeure, unforeseen circumstances and good faith. Another way of looking at judicial application of contract law during the Great War is to consider this as an extension of the Dutch neutrality doctrine. Both viewpoints are explored in this article.
\end{abstract}

\section{INTRODUCTION}

Throughout the Great War, the Kingdom of the Netherlands tried frantically to maintain a position of armed neutrality between the Central Powers and the Entente Forces. ${ }^{1}$ While it more or less succeeded in doing so, unsurprisingly the war did leave distinct marks on Dutch society and economy. These marks eventually translated into legal change. Therefore, in hindsight, the impact of the Great War on Dutch law and regulation was enduring and lasting, even though this was not always appreciated at the time.

\footnotetext{
${ }^{1}$ On the Dutch neutrality doctrine see eg C Smit, Nederland in de Eerste Wereldoorlog-deel 2 1914-1917 (Wolters-Noordhoff, 1972) 12 ff; EH Kossmann, The Low Countries 1780-1940 (Clarendon Press, 1978) 546 ff; P Moeyes, Buiten Schot: Nederland tijdens de Eerste Wereldoorlog (Arbeiderspers, 2001) 27 ff; MM Abbenhuis, The Art of Staying Neutral: The Netherlands in the First World War, 1914-1918 (Amsterdam University Press, 2006) 23 ff; I Tames, Oorlog voor onze gedachten: Oorlog, neutraliteit en identiteit in het Nederlandse publieke debat 1914-1918 (diss A'dam) (Verloren, 2006) 14 ff; S Kruizinga, Overlegeconomie in oorlogstijd: De Nederlandsche Overzee Trustmaatschappij en de Eerste Wereldoorlog (Walburg Pers, 2012) 16.
} 
In this contribution, I provide a partial analysis of that impact. I do so by first briefly discussing the impact of the war on Dutch society and economy and explaining the peculiar role that its private law system played in keeping Dutch international trade afloat (section II). The discussion serves to sketch the background against which we should understand the development of two key contract law doctrines-impossibility and force majeure (vis maior) - in Dutch case law and academic legal debate (section III). Next, we turn to the influence of the Great War on the slow and gradual development of the good faith principle and the doctrine of unforeseen circumstances in Dutch law (section IV). Finally, Dutch contract law is considered in terms of its contribution to the Dutch neutrality doctrine during the Great War (section IV).

\section{THE GREAT WAR AND DUTCH SOCIETY \& ECONOMY}

At the beginning of the war it was clear that the Dutch government was ill prepared for the economic consequences of an outbreak of hostilities between so many countries. There was no robust legal framework for dealing with the immediate problems caused by the outbreak of war. ${ }^{2}$ These problems included a sudden decline in trust in bank institutions, a run on banks, and hoarding of coinage. ${ }^{3}$ The disruption of the finance system, leaving investors facing acute liquidity problems, led to the hurried closure of the Amsterdam stock exchange. ${ }^{4}$ At the same time, the sudden interruption in the importation of essential foodstuffs, and the distributional issues these shortages led to, created new problems for supplying the market. ${ }^{5}$ These problems were unparalleled in scale and as such prompted the introduction of interventionist emergency legislation at odds with the economic laissez-faire policies that had been predominant until then. So, as in other countries, ${ }^{6}$ the war heralded the end of laissez-faire economic policies and the start of more intense regulation of certain

\footnotetext{
2 AH Flierman, 'Het centrale punt in de reederswereld': De Koninklijke Nederlandse Redersvereniging, 19051980 (diss Leiden) (De Boer Maritiem, 1984) 43 ff.

${ }^{3} \mathrm{G}$ Vissering and J Westerman Holstijn, 'The Effect of the War upon Banking and Currency' in HWC Bordewijk, G Vissering and J Westerman Holstijn (eds), The Netherlands and the World War: Studies in the War History of a Neutral, vol 4 (Economic and Social History of the World War-Netherlands Series, Yale University Press for the Carnegie Endowment for International Peace, 1928) 4; J van der Flier, War Finances in the Netherlands up to 1918 (Economic and Social History of the World War-Dutch Series, Clarendon Press for the Carnegie Endowment for International Peace, 1923) 21. Interestingly, the sudden demise of public trust in banking institutions caused strikingly similar problems on the London markets (though obviously on a larger scale). Cf $R$ Roberts, Saving the City: The Great Financial Crisis of 1914 (Oxford University Press, 2013) 3 ff.

${ }^{4}$ On the so-called 'prolongation' system of financing stock market investments and the abrupt liquidity problems it caused in July 1914, see eg Vissering and Westerman Holstijn (n 3) 5 ff, 80; F de Roos, De algemene banken in Nederland (Oosthoek, 1949) 90 ff; Kruizinga (n 1) 18. The acute problems in banking and stock trade were similar to those experienced elsewhere; see Roberts ( $n 3)$.

${ }^{5}$ Moeyes (n 1) 274.

${ }^{6}$ Cf R Overy, The Morbid Age: Britain and the Crisis of Civilization, 1919-1939 (Penguin, 2010) 50 ff; H Dörner, 'Erster Weltkrieg und Privatrecht' (1986) 17 Rechtstheorie 385, $397 \mathrm{ff.}$
} 
markets such as food production, financial services and housing. ${ }^{7}$ Apart from emergency legislation on banking, currency, insurance and stock trade, a long list of new and lasting market legislation was introduced between 1914 and 1919. The Foodstuffs Act (Levensmiddelenwet 1914) and the Distribution Act (Distributiewet 1916) regulated production, supply, pricing and distribution of certain essential goods. ${ }^{8}$ New powers introduced in 1914 under the Expropriation Act (Onteigeningswet 1851) authorised the government to requisition goods. ${ }^{9}$ Several Acts concerning the protection of tenants were introduced to protect against termination at will and to fix prices in order to stabilise the nervous housing market. ${ }^{10}$ And, to top it all, the revolutionary ghost that haunted Europe sped up the introduction of universal suffrage (in 1917 for men and in 1919 for women). In September 1914, four eminent businessmen took the initiative of setting up a committee of trading companies, banks and shipping companies to deal with trade problems caused by the British authorities. The British fleet effectively controlled sea access to Dutch harbours. The British authorities demanded assurances that conditional contraband such as DutchIndies tobacco and foodstuffs en route to the Netherlands would not be exported from the Netherlands to any of the Central Power countries and were destined for home consumption only. The dilemma for the Dutch government was that it did not want to be seen as agreeing to terms dictated by either of the belligerents, but it had to reckon with duties to Germany under the 1868 Convention for Navigation on the Rhine (the Mannheim Document) and it wanted to keep the Dutch and colonial trade economy afloat as much as possible. ${ }^{11}$ At first, the government decided not to openly assume any obligations vis-à-vis the British. ${ }^{12}$ Instead, it relied on the private initiative of the four businessmen, who duly incorporated their initiative as the NV Nederlandsche Overzee Trustmaatschappij (NOT), the Netherlands Overseas Trust Company. ${ }^{13}$

The NOT worked on the contract principle that shipping and import companies voluntarily subscribed to the NOT scheme and that by doing so they assured that any imports of conditional contraband into the Netherlands would either remain in the Netherlands or

\footnotetext{
${ }^{7}$ Cf P De Rooy, Republiek van rivaliteiten: Nederland sinds 1813 (Wereldbibliotheek, 5th edn 2014) 142, who refers to this development as the 'entwinement of markets and politics'.

${ }^{8}$ Government subsidies were also distributed, especially to sustain the building industry; see HWC Bordewijk, 'War Finances in the Netherlands, 1918-1922: the Costs of War' in Bordewijk et al (n 3) 153.

${ }^{9} \mathrm{M}$ Kraaijestein, 'Lokale noden en lokaal beleid' in H Binneveld (ed), Leven naast de catastrofe: Nederland tijdens de Eerste Wereldoorlog (Verloren, 2001) $64 \mathrm{ff.}$

${ }^{10} \mathrm{HJ}$ Romeyn, 'The Housing Problem' in CJP Zaalberg et al (eds), The Netherlands and the World War: Studies in the War History of a Neutral, vol 2 (Economic and Social History of the World War-Netherlands Series, Yale University Press for the Carnegie Endowment for International Peace, 1928) $181 \mathrm{ff}$.

${ }^{11}$ Smit (n 1) 69 ff; cf Kossmann (n 1) 545 ff.

${ }^{12}$ Kruizinga (n 1) $49 \mathrm{ff}$.

${ }^{13}$ The NOT was a not-for-profit organisation; any profits the NOT made were donated to the War Relief Fund and the State. Note, however, that the NOT Board members' main occupation was with commercial companies that undoubtedly benefited from the war conditions and their key position within the Dutch war trade framework. See Kruizinga (n 1) 105.
} 
were exported only to neutral third countries. Thus, shipments to the Netherlands were subject to a NOT import consent. The legal status of such undertakings ('consents' in Dutch) was hybrid: officially, the NOT was a mere private actor which operated on the basis of contract, but in the international war theatre NOT consents were ascribed the status of safe passage documentation. ${ }^{14}$

Based on this voluntary arrangement, shipping and/or import companies that underwrote and then breached the NOT rules would be fined heavily and blacklisted. Those traders that refused to follow the NOT rules were not as such criminally liable ${ }^{15}$ under Dutch law, but their goods did run the risk of being stopped and confiscated by the British admiralty, and once harboured in the Netherlands they were effectively excluded from access to goods and services as a result of the high degree of commitment of Dutch traders and businesses. The contractual basis made the arrangement slightly more palatable for the companies involved, and it was rather successful in the first two years of the war, although admittedly there was also a thriving semi-legal and illegal export trade of goods to the German hinterland. The Germans obviously saw through the smoke and mirrors of a private organisation executing the implicit Dutch government policies on an English leash. They reasoned, however, that any importation into the Netherlands was to be preferred over no importation at all, since goods on Dutch soil could still somehow find their way to German buyers. Thus, neutrality of the Netherlands was in keeping with the German strategy of having the Rotterdam harbour as a Luftröhre (windpipe) for the German economy. ${ }^{16}$ The voluntary basis of compliance with the NOT rules caused civil courts some headaches at a later stage of the war. Since the NOT was not an official part of government and their framework of fining and blacklisting was not based on statutory powers, how could NOT actions and decisions affect the contractual relationships between sellers and buyers? NOT rules which rendered performance of contracts factually impossible were obviously not equal to legal impossibility. Some courts did however hold that a debtor giving priority to NOT rules instead of his duties under the contract could be excused in view of the reputational risks and the risk of ostracism he would run. ${ }^{17}$

\footnotetext{
${ }^{14}$ On the contractual nature of the NOT framework see eg Kruizinga (n 1) $107 \mathrm{ff}$. Cf Rechtbank Amsterdam 8 June 1917, Nederlandse Jurisprudentie (NJ; Dutch Court Cases Digest) 1917, 807 (Handelsvennootschap onder firma Behrendt \& Bodenheimer v Handelsvennootschap onder firma Gebrs. Sickesz); Rechtbank Rotterdam, 17 January 1918, NJ 1919, 306 (NV Firma M Cohn v Nolet).

${ }^{15}$ Cf Rechtbank Rotterdam, 17 November 1916, NJ 1918, 1025 (Vignati v Schepens).

${ }^{16}$ Moeyes (n 1) 192; Abbenhuis (n 1) 185; De Rooy (n 7) 138; N Ferguson, The Pity of War (Penguin, 1999) 97.

${ }^{17}$ eg Rechtbank (ie Court of First Instance) Amsterdam, 26 May 1916, NJ 1917, 361 (Handelsvennootschap onder de firma Wood \& Co v NV Curaçaosche Handelmaatschappij); Rechtbank Rotterdam, 10 January 1917, NJ 1917, 658 (Polak v Handelsvennootschap onder firma H Jacobs); Gerechtshof (ie, Court of Appeal, also referred to as 'Hof') Den Haag, 12 May 1919, Weekblad van het Recht (W) 1920, no 105923, 4 (Bakker v Handelsvennootschap onder Firma Behrendt en Bodenheimer, NV Maatschappij tot Exploitatie van Rademakers Koninklijke Cacao- en Chocolade fabrieken).
} 
In the long run, the voluntary basis of the NOT proved inadequate. Conditions for international trade and commercial shipping deteriorated rapidly. Although at the start of the war it seemed that the British would adhere to the 1909 London Declaration, practice proved to be less principled. ${ }^{18}$ The British listing of absolute and conditional contraband changed frequently, necessitating continuous (re)negotiation of import and export terms by the NOT and the Dutch government with British and German representatives. ${ }^{19}$ This put the NOT and the Dutch government in a state of incessant uncertainty. On the one hand there was the British government's total naval blockade, which mean that it effectively ruled the North Sea waves and could therefore extract almost any deal from the Netherlands, provided it did not overtly overstep the magical boundaries of international diplomacy and thus risk the Netherlands openly siding with the Germans. On the other there were the Germans, whose 'Hinterland' was hugely important for the exportation of Dutch agricultural produce and industrial products and who were keen to ensure that Dutch neutrality was observed in both directions so that it too could profit from what few goods could be passed on. $^{20}$

Moreover, the Netherlands, having few domestic mineral resources such as coal and iron ore, was greatly reliant on both overseas and overland import of such raw materials. The Netherlands also depended on trade with the Dutch Indies colonies (for items such as coffee and tobacco), and so it tried hard to minimise the disruptive effects of the naval blockade on the flow of goods where and when it could. That said, being a country with an open economy, remaining neutral in a global war amidst the main protagonists hardly offers any guarantees of escaping unscathed; the intensity of the German submarine warfare strategy and the Allied strategy of suffocating the German economy inevitably caused collateral damage to neutrals such as the Netherlands. ${ }^{21}$ Shortages of most materials meant that prices shot up, provided they were still available. The ongoing war caught the NOT in an increasingly incoherent web of a private regulatory scheme which overlapped with growing state intervention of import and export licenses, bans and restrictions. While the NOT

\footnotetext{
${ }^{18}$ Moeyes (n 1) 181 ff; C Smit, Tien studiën betreffende Nederland in de Eerste Wereldoorlog (HD Tjeenk Willink, 1975) 80 ff; Kruizinga (n 1) 25 ff. It seems that David Lloyd George presaged this British dilemma; see Ferguson (n 16) 66.

${ }^{19}$ eg JG Hoogendijk, De Nederlandsche Koopvaardij in den Oorlogstijd (1914-1918) (Van Holkema \& Warendorf, 1930) $19 \mathrm{ff}$.

${ }^{20}$ On the economic ties between Germany and the Netherlands in this era, see eg $\mathrm{H}$ de Jong, 'Between the Devil and The Deep Blue Sea: The Dutch Economy during World War I' in S Broadberry and M Harrison (eds), The Economics of World War I (Cambridge University Press, 2005) 137 ff; HAM Klemann, 'Wirtschaftliche Verflechtung im Schatten zweier Kriege 1914-1940' in HAM Klemann and F Wielenga (eds), Deutschland und die Niederlande: Wirtschaftsbeziehungen im 19 und 20 Jahrhundert (Waxmann, 2009) 19; Kruizinga (n 1) 22 ff. ${ }^{21}$ Abbenhuis (n 1) $117 \mathrm{ff}$. Dutch neutrality was further jeopardised by the 1917 USA export ban on neutrals and ultimately effectively violated by the 1918 requisitioning by the Allied forces of the Dutch commercial fleet, which was the ultimate blow to the Dutch neutrality doctrine. Cf Hoogendijk (n 19) 34.
} 
provided a convenient façade in the first years of the war, it gradually became an odd marriage of (in)convenience for businessmen and policymakers.

For some Dutch traders, the war economy opened up opportunities for profiteering and abuse of war conditions. ${ }^{22}$ The lower classes, which did not directly profit and in fact saw both the cost of living and unemployment figures rise steadily during the War, ${ }^{23}$ increasingly voiced their discontent through demonstrations, looting and so-called 'war food riots', which were seemingly prompted more by discontent and a perceived growth of inequality than by genuine starvation. ${ }^{24}$ The timely introduction of general suffrage, social reform and the relative popularity of the House of Orange contributed to averting a 1918 self-proclaimed socialist revolution from taking root.

This brief introduction to the effects of the Great War on Dutch society and economy serves as a stepping stone towards the subject of this paper: the influence of the Great War on Dutch contract law. Given the radical changes to economic conditions brought about by the war, the period under review saw extensive repudiation and renegotiation of sales and services contracts which led to a substantial amount of litigation, raising important doctrinal questions involving issues of performance, rescission and damages.

\section{BREACH, IMPOSSIBILITY AND FORCE MAJEURE}

\section{General Introduction}

At the time of the Great War, the 1838 Dutch Civil Code (DCC) was in force. This code was by and large a continuation of the 1804 Code Napoleon, which had been in force in the Dutch territories since the French annexation of the Netherlands in 1810. The Code distinguished between culpable and non-culpable non-performance-that is, between actionable breach

\footnotetext{
${ }^{22}$ On war profits, see Moeyes (n 1) 328, 379 ff; Kruizinga (n 1) 113 ff, 167, 249, 313; Van der Flier (n 3 ) $101 \mathrm{ff}$. See also Vissering and Westerman Holstijn (n 3) 21, who argue that the Netherlands became a 'creditor nation' as a result of the war. For instance, loans to the German Reich in exchange for coal supplies sold by the Germans and as vendor's credit for purchases by the Germans under of the 1916 Hindenburg Program, combined with the continued devaluation of the Reichsmark against the Dutch guilder, yielded substantial financial gains for the Dutch. Cf Kruizinga (n 1) $261 \mathrm{ff} ; \mathrm{H}$ Strachan, Financing the First World War (Oxford University Press, 2004) 166; D Stevenson, With our Backs to the Wall: Victory and Defeat in 1918 (Penguin, 2012) 421; A Gaaff, Financiering van de Eerste Wereldoorlog: Vier jaar vechten op krediet (Uitgeverij Aspekt, 2014). On balance, the Dutch economy suffered less than others: see De Jong (n 20) $137 \mathrm{ff}$; H-P Ullmann, 'Finance' in J Winter (ed), The Cambridge History of the First World War, vol 2: The State (Cambridge University Press, 2014) 428; E Damsgaard Hansen, European Economic History: From Mercantilism to Maastricht and Beyond (CBS Press, 2012) 226.

${ }^{23}$ On 1914-19 unemployment figures see eg De Jong (n 20) 137 ff; Van der Flier (n 3) 107 ff.

${ }^{24} \mathrm{~J}$ Visser and M Visser, 'Profijt en protest: Verscherping der sociale tegenstellingen in Nederland gedurende de Eerste Wereldoorlog' in $\mathrm{H}$ Binneveld (ed), Leven naast de catastrofe: Nederland tijdens de Eerste Wereldoorlog (Verloren, 2001) 103-4. Note, however, that the American export ban and requisitioning of the Dutch commercial fleet in 1917-18 did cause significant supply problems for the Netherlands; see Ferguson (n 16) 253.
} 
and impossibility due to vis maior. Breach of contract authorised the creditor to petition the court for rescission ab initio. ${ }^{25}$ In practice, parties could insert a termination clause in their contract to allow for unilateral termination without court involvement in case of breach. Furthermore, breach implied culpability and that in itself offered the basis for a cause of action for damages. By contrast, vis maior of one party ended the contract and discharged both parties from any duty to perform. ${ }^{26}$

According to Articles 1280-1 DCC, the debtor (which is the generic term used to denote the party who is under a duty to perform any obligation, be it to deliver or to pay an amount in money etc) was liable to pay damages in case of non-performance unless he could prove 'toeval', 'vreemde oorzaak' or 'overmagt' ${ }^{27}$ These exceptions all denoted the same concept of vis maior, a non-culpable externality for which the debtor does not bear responsibility (neither for reasons of culpability nor for reasons of risk assumption). Thus, liability for breach of contract by non-performance was predicated on a presumed fault of the debtor. If he could disprove fault and thus establish vis maior, liability did not attach. ${ }^{28}$

Furthermore, where the debtor was under a duty to deliver a particular object, as in a sales contract, the concept of 'impossibility' came into play. According to Article 1480 DCC (= Article 1302 Code Napoleon), an obligation to deliver an identifiable object was considered extinguished if the object perished due to a non-culpable cause. Thus, Article 1480 DCC contained a doctrine of impossibility: if it was impossible to deliver due to vis maior, the obligation to deliver ceased as well and the debtor was released from any duty to pay damages as much as the other party was released from paying the agreed sum. ${ }^{29}$ So, in contract law, the concepts of impossibility (to deliver) and vis maior enshrined in Articles 1280 and 1480 DCC were more or less entwined: if performance was impossible due to a cause for which the debtor bore no responsibility, the contract was discharged without further amendment or variation. If, however, performance was perfectly possible, there was no impossibility and therefore no vis maior. Therefore, in court cases as well as in scholarly debates, the emphasis tended to be on what constituted impossibility rather than on what were the limits of culpability or imputability of risk. As a consequence, these two elements

\footnotetext{
${ }^{25}$ Hoge Raad der Nederlanden (Supreme Court of the Netherlands; abbrev HR), 25 February 1916, W 1916 no 10022 (Loeb v Mulderije).

${ }^{26}$ Rechtbank Rotterdam, 15 January 1914, NJ 1914, 325 (Wipmuller v NV Hollandsche Aanneming Maatschappij).

${ }^{27}$ Arts 1280-1 DCC were based on Arts 1147-8 Code Napoleon ('cause étrangère', 'force majeure', 'cas fortuit'). From the 19th and early 20th centuries onwards, Dutch contract law doctrine held that there was no substantive difference between 'cause étrangère', 'force majeure' and 'cas fortuit'. For references, see LEH Rutten, Mr C Asser's Handleiding tot de beoefening van het Nederlandsch Burgerlijk Recht-Derde deelVerbintenissenrecht-Eerst stuk-De verbintenis (WEJ Tjeenk Willink, 3rd edn 1967) 248.

${ }^{28}$ HR, 20 June 1919, NJ 1919, 811 (NV Haagsche Tramweg Maatschappij v Kuys).

${ }^{29}$ HR, 7 May 1925, NJ 1925, 997 (Baumwollspinnerei Kolbermoor v Van Kempen qq). Cf Rechtbank Amsterdam, 23 June 1920, NJ 1921, 1160 (Comm Handelsvennootschap o/d firma Textielhuis 'Nederland' $v$ Handelsvennootschap o/d firma Amsterdamsche Confectiefabriek R Doyes \& Co).
} 
were often blurred into one wider test of contract risk allocation predicated on impossibility. ${ }^{30}$

\section{Non-Culpable Impossibility in War Cases}

The Great War was the first major systemic test of the Civil Code provisions on contract risk allocation. It was the first global armed conflict of substance in which the Netherlands had been involved since the proclamation of the Kingdom in 1815. Obviously, there had been multiple international conflicts which had had some impact on the Netherlands (such as the 1830 secession of Belgium, the 1870-71 Franco-Prussian War and several colonial conflicts), but none of these were of the disruptive nature and scale of the Great War. Therefore, it is relevant to analyse the judicial application in war-related cases of such doctrines as breach of contract, impossibility and vis maior.

In court proceedings, the facts underpinning the vis maior defence needed to be stated and, if contested, proved by the debtor. ${ }^{31}$ He was to prove that the obstruction to performance existed at the time the contractual obligation was due (neither earlier nor later). ${ }^{32}$ As we shall see, in war cases evidence of vis maior was far from easy to bring. The mere fact of the outbreak of war was clearly insufficient. Moreover, the war in itself did not render existing contracts illegal since restrictions on trading with belligerents were (at first) absent. ${ }^{33}$ Among the most successful vis maior defences were cases involving lack of cargo capacity to ship the goods, ${ }^{34}$ governments requisitioning goods, ${ }^{35}$ and transport and export restrictions rendering delivery impossible. ${ }^{36}$

All in all, the number of court cases where the debtor was excused for non-performance was greatly outnumbered by the number of cases where the debtor was held liable for breach. The defendant had to prove that he had done everything reasonably possible to honour his

\footnotetext{
${ }^{30}$ For an overview of this development, see Rutten (n 27) $247 \mathrm{ff}$.

${ }^{31}$ eg Rechtbank Amsterdam, 4 April 1919, W 1920, no 10580, 4 (J van Heijningen v NV Weduwe IT Numan's Blikfabrieken) partially confirmed by Gerechtshof Amsterdam, 11 November 1921, W 1922 no 10833, 1; Gerechtshof Amsterdam, 27 October 1920, Weekblad voor Privaatrecht, Notariaat en Registratie (WPNR) 1922, no $2715,4$.

${ }^{32}$ HR, 22 March 1918, W 1918, no 10265, NJ 1918, 481 (NV Wessanen's Koninklijke Fabrieken v Suijling broodfabrikant); on appeal from Gerechtshof 's-Hertogenbosch, 3 April 1917, NJ 1917, 591, WPNR 1918, no 2512, 87.

${ }^{33}$ Gerechtshof Den Bosch, 13 November 1917, NJ 1918, 405 (Neles v De Voghel); Gerechtshof Amsterdam, 14 February 1923, W 1923, no 11088, 3 , NJ 1924, 212 (Polet v Firma E Gilmant \& Cie (Soignies, Belgium)).

${ }^{34}$ Rechtbank Rotterdam, 28 October 1915, NJ 1916, 423 (Handelsvennootschap onder firma Henri J Hool v Handelsvennootschap onder firm Friede Knurr).

${ }^{35}$ Gerechtshof Den Haag, 4 December 1916, NJ 1917, 278 (Firma JN van der Reijden v Van den Oord).

${ }^{36}$ Rechtbank Leeuwarden, 21 October 1920, NJ 1921, 145 (Firma Gebr Woudstra v Okkinga); Rechtbank Utrecht, 26 June 1918, WPNR 1918, no 2547, 473 (Société Anonyme Pégase v Utrechtsche Machinefabriek v/h Smulders \& Co).
} 
contractual obligations. ${ }^{37}$ So, if for instance the debtor argued that government restrictions had been imposed (on transport, export, production, etc), he should also bring evidence that he had applied for a concession and had done so in a timely and diligent fashion, since disproving fault implied bringing evidence of utmost diligence. ${ }^{38}$

War cases show that the courts were generally reticent to sustain the debtor's defence of impossibility. ${ }^{39}$ Debtors encountered sceptical courts. ${ }^{40}$ For instance, a supplier of English coal who argued impossibility was rebuked by the court since all sorts of coal were exported all the time from England to Holland. ${ }^{41}$ It seems that debtors had acquired a dubious reputation in the early days of the war by seemingly attempting to shirk their existing responsibilities as the outbreak of war opened up opportunities to make more profit under new contracts. For instance, when the government imposed a price ceiling for the sale of wheat flour, some sellers who had already entered into contracts with prices negotiated at a lower amount were keen to argue that the imposed tariffs constituted both a minimum price as well as a ceiling and that delivery at the original price was thus impossible. ${ }^{42}$ In response, it was argued by some scholars that debtors should not be easily let off the hook. Instead, these scholars posited, 'faced with great disasters, great endeavours shall be expected from debtors', ${ }^{43}$ and extraordinary price hikes should not exonerate debtors from performance. ${ }^{44}$

\footnotetext{
${ }^{37}$ Rechtbank Amsterdam, 12 November 1915, NJ 1916, 427 (Handelsvennootschap onder firma Van Zweeden en Co v NVM Witsenburg Jr's Agentuur en Commissiehandel), confirmed by the Amsterdam Court of Appeal (Gerechtshof Amsterdam, 6 October 1916, NJ 1917, 275); Gerechtshof Amsterdam, 23 January 1920, NJ 1920, 396 (NH onder firma Van Wessem \& Co te Zaandam v HV onder firma Spliethoff Hass \& Co Te Amsterdam). ${ }^{38}$ eg Rechtbank Breda, 14 January 1919, NJ 1919, 382 (Hout- en Grond-Exploitatie-Maatschappij 'Arbor' v Daems); Rechtbank Rotterdam 11 June 1919, W 1920 no 10509, 2 (Jensen v NV van Steen's Rijnreederij); Rechtbank Den Bosch, 30 April 1920, W 1921, no 10703, 4 (Klerx v Waisvisz).

${ }^{39}$ JLL Wery, Overmacht bij overeenkomsten (Akad Prft Leiden) (Kruyt, 1919) 132; P Abas, Beperkende werking van de goede trouw (Kluwer, 1972) 110.

${ }^{40}$ Arbitration panel Van der Horst, Wollring, Boekenoogen, 14 October 1914, WPNR 1914, no 2341, 509 (Offermeier v Handelsvennootschap onder firma H Gerritsen); Rechtbank Utrecht, 15 December 1915, WPNR 1916, no 2448, 572; Rechtbank Rotterdam, 8 December 1915, NJ 1916, 435 (NV Magnesitfabrieken voorheen Rosenboom en Co v NV Magnesiet Exploitatie Maatschappij); Rechtbank Utrecht, 12 January 1916, NJ 1916, 1056 (Hesp v NV Jutphaasche Olie slagerij); Rechtbank Alkmaar, 15 November 1917, NJ 1918, 485 (NV Turness' Scheepvaart en Agentuur Maatschappij v Burgemeester Houwing qq); Rechtbank Amsterdam, 13 March 1918, NJ 1918, 854 (Festin v Handelsvennootschap onder firma Drukker, Vigeveno \& Co); Rechtbank Alkmaar, 23 May 1918, NJ 1919, 19 (Crucq v NV Landbouwkantoor Noord-Holland); Gerechtshof Arnhem, 28 March 1923, NJ 1924, 170 (Schut v Kempeneers).

${ }^{41}$ Rechtbank Rotterdam, 5 October 1916, NJ 1918, 1030 (Coöperatieve Veevoederfabriek en Olieslagerij 'De Boerenbond' $v$ Handelsvennootschap onder firma Jos de Poorter).

${ }^{42}$ Rechtbank Haarlem, 20 October 1914, WPNR 1914, no 2341, 507 (Flink v NV Koninklijke Fabrieken voorheen Wessanen en Laan), upheld on appeal by Gerechtshof Amsterdam, 12 March 1915; Rechtbank Amsterdam, 4 December 1914, WPNR 1915, no 2351, 32 (Bakery Marcelis v Wicherlink); HR, 25 June 1915, WPNR 1915, no 2388,497 finally settled the argument by holding that the new statutory powers of local authorities to requisition in fact implied impossibility to perform.

${ }^{43}$ P Scholten, 'Het recht tegenover de huidige crisis: Overmacht bij leveringscontracten' [1914] Weeklad voor Privaatrecht, Notariaat en Registratie (WPNR) 417, 418.

${ }^{44}$ WLPA Molengraaff, De gevolgen van den oorlog op handelsovereenkomsten, in het bijzonder op leveringscontracten (A Oosthoek, 1915) 16.
} 
Judging by the fact that in most court cases the debtor was not excused for breaching his obligations, it seems that these calls resonated strongly with the judiciary.

A further issue was the construction of contractual obligations. Courts were mostly unwilling to read more debtor-friendly terms into contracts than debtors themselves had negotiated into them. For instance, in a 1917 contract for the delivery of 'Belgian oak' casks, the subject matter was deemed only to identify the provenance of the casks, not their location at the time of sale. So, the seller was not allowed to argue impossibility if he intended to import the casks from Belgium, where such import had become impossible. ${ }^{45}$ Whenever a contract was considered to be one for generic goods, the debtor could not easily be excused for nonperformance (genus non perit). ${ }^{46}$ Likewise, if a seller promised to take care of transport but did not specify the means, he could not be excused if the mode of transport he contemplated was no longer available but others still were. ${ }^{47}$

Once the war conditions had become part of daily life, contracting parties were expected to guard their interests by not promising more than they could deliver. For instance, in Keller $v$ Oosterveld \& Romijn, an English buyer entered into a contract for the delivery of 'Prussian blue' (a paint dye) by a Dutch seller in December 1914. The goods were to be delivered to the buyer in Amsterdam in early 1915, with a warranty of 'neutral origin' so that the buyer could export the dye. The seller was unable to obtain the raw materials for the dye anywhere other than in Germany, and the export restrictions on such materials were tightened in a matter of weeks. The defence of excusable impossibility was rejected by the court by simply arguing that a debtor who assumes a duty to deliver certain goods must assure himself of the availability of such goods. ${ }^{48}$ In Aktien Gesellschaft Mechanische Weberei $v$ De Vries, a Dutch seller promised to deliver fabric for the manufacture of bandages under the guarantee of 'export allowed' to a German buyer. However, the export of the goods was unexpectedly prohibited by the authorities and the seller alleged that the prohibition had come as a surprise. The court held, however, that since export prohibitions

\footnotetext{
${ }^{45}$ Gerechtshof Amsterdam, 9 October 1919, NJ 1920, 249 (Simon v Holst). Cf Gerechtshof Arnhem, 15 June 1920, NJ 1920, 1068. Note the similarities and differences in approach with Blackburn Bobbin Co Ltd v TW Allen and Sons Ltd [1918] 1 KB 540 (KBD), discussed by MacMillan in this issue.

${ }^{46}$ Gerechtshof Amsterdam, 30 April 1919, W 1920, no 10588, 3 (Handelsvennootschap onder de firma Roskopf en Schoemaker v De Korver). Cf Gerechtshof Arnhem, 28 March 1923, W 1923, no 11052, 2 (Schut v

Kempeneers); Gerechtshof's-Gravenhage, 11 November 1929, W 1929, no 12056, 3 (Boichel v NV

Amsterdamsche Ballast Mij). See also Rechtbank Amsterdam, 1 June 1923, W 1923, no 11222, 2, where a Dutch seller was unable to deliver iron wire because he could not reach his German supplier as a consequence of the occupation of the Ruhr (January 1923-August 1925). The court held that the seller was in breach of his duties under the contract since the contract did not stipulate that the wire had to be of German origin.

${ }^{47}$ Rechtbank Den Bosch, 24 June 1921, W 1922, no 10919, 3 (Hildebrand v Klapwijk).

${ }^{48}$ Rechtbank Amsterdam, 14 April 1916, W 1917, no 10087, 2 (Keller (London) v Firma Oosterveld en Romijn (Zaandam, the Netherlands)). In a similar vein, Rechtbank Zwolle 19 December 1917, NJ 1918, 174 (Van Kuyk v firma De Vogel van Calcar \& Co).
} 
were introduced frequently and changed often, the seller could not be excused by reference to the unexpected prohibition. ${ }^{49}$

\section{Assumption of Risk and Foreseeable Obstacles}

Where agreements had been entered into at a point in the war when parties had to reckon with further deterioration of market conditions, courts usually found that such future obstacles had been foreseeable at the time of conclusion of the contract. The legal reasoning applied in these cases typically was that a debtor who knowingly assumed certain obligations, cognisant of the fact that there was a war going on and of how the war had until then affected supplies, licensing and transport, voluntarily assumed the risk of further problems unless he explicitly excluded such risks. ${ }^{50}$ Moreover, when reviewing the court decisions on war conditions and vis maior, it is striking to find so many cases in which a burgeoning concept of 'assumption of risk' by the debtor plays a pivotal role in the attribution of risk for impossibility. ${ }^{51}$ For instance, one court held that where a seller in wartime assumes an obligation under the explicit condition to deliver 'with permission' (ie, 'including export licence'), he has taken upon himself the risk of not obtaining the required export licence. ${ }^{52}$ The use of this concept of 'voluntary assumption of a risk' seems to have

\footnotetext{
${ }^{49}$ Gerechtshof Amsterdam, 16 January 1920, W 1920, no 10552, 2 (Aktien Gesellschaft Mechanische Weberei te Zittau v Firma SI de Vries te Amsterdam).

${ }^{50}$ See eg Rechtbank Rotterdam, 16 December 1915, NJ 1916, 432 (Rohn v Handelsvennootschap onder de firma GJ Dekkers); Rechtbank Rotterdam, 1 February 1917, NJ 1918, 1031 (Tempelaars v firma Jos de Poorter); Rechtbank Den Haag, 20 April 1916, WPNR 1916, no 2423, 278 (Wijzenbeek v An Englishman); Rechtbank Amsterdam, 7 March 1917, NJ 1917, 809 (Handelsvennootschap onder firma Feldmann \& Co v Firma Van Cleeff Hessian Cy); Gerechtshof Arnhem, 27 March 1917, NJ 1917, 881 (Handelsvennootschap onder firma WA Gerritsen \& Zn v graanhandelaar Reijers); Rechtbank Utrecht, 18 April 1917, NJ 1917, 1059; Gerechtshof Den Haag, 26 June 1917, NJ 1917, 863 (Zwarts v Latenstein van Voorst); Rechtbank Amsterdam, 25 June 1917, NJ 1917, 877 (NV Maatschappij voor Commissiehandel v Amsterdamsch Handelskantoor); Rechtbank Rotterdam, 7 February 1918, NJ 1918, 1045 (Engelsche Vennootschap Van den Bergh Limited v Vennootschap Swift \& Company); Rechtbank Amsterdam, 7 June 1918, NJ 1918, 853 (Duives v Handelsvennootschap onder firma Van Doel en Fray); Rechtbank Breda, 25 June 1918, NJ 1919, 52 (Van Berkel v handelsvennootschap onder firma PW van Lisdonk \& Co); Gerechtshof Den Haag, 28 June 1918, NJ 1918, 1028; Gerechtshof Den Bosch, 15 February 1921, NJ 1921, 700, W 1921, no 10707, 3 (Handelsvennootschap onder de firma Wed A Maassen (Liege) v A Knols (Maastricht)); Gerechtshof Arnhem, 20 July 1922, W 1923, no 10972, 1 (Van Meerveld v NV Stoomvaartmaatschappij 'Princenhage').

${ }^{51}$ Rechtbank Rotterdam, 5 October 1916, NJ 1917, 883 (Van der Graaf v Beukers cacaofabrikant); Gerechtshof Den Bosch, 25 September 1917, NJ 1918, 356 (Völker v Handelsvennootschap de Clever Pflanzer-butterfabrik); Rechtbank Haarlem, 6 November 1917, NJ 1918, 176, confirmed by Gerechtshof Amsterdam, 26 May 1919, NJ 1920, 212 (Zaman v NV Haarlemsche Stoomzeepfabriek 'Het Klaverblad'); Rechtbank Maastricht, 21 February 1918 NJ 1918, 407 (Gebroeders van A v JA); Rechtbank Amsterdam, 31 May 1918, NJ 1918, 857 (Mari v Wijzenbeek); Rechtbank Den Bosch, 20 December 1918, NJ 1919, 635 (Firma Jos Bots v Walter); Rechtbank Haarlem, 13 May 1919, NJ 1919, 700 (Stein Hirsch \& Co te New York v NV Haarlemsche Stoomverffabriek voorheen $W$ Leur \& Co ).

52 Rechtbank Amsterdam, 18 October 1918, NJ 1919, 55 (handelsvennootschap onder firma Behrendt en Bodenheimer (Hamburg) v Henniès); Rechtbank Dordrecht, 23 April 1919, NJ 1919, 612 (Vetter v Drinkwaard).
} 
tacitly extended the basis for contractual liability from a mere fault basis to a broader risk basis.

In a minority of cases, impossibility of performance was considered unforeseeable at the time of entry into contract. ${ }^{53}$ These cases generally contained an element of long-term commitment. ${ }^{54}$ For instance, in Kroon $v$ Nord Thomson, the court had to consider a five-year contract agreed in August 1914 for the delivery of pudding sachets. By 1917, the delivery of pudding concentrates became impossible due to government restrictions. The buyer argued that the seller had assumed the risk of war conditions since he entered into the contract when war had already broken out. The court found, however, that the parties could not have contemplated in August 1914 that the war would continue for so long. Given that this was a contract for supply of goods manufactured by the seller himself, that no one could have foreseen the duration of the war, and in light of the import restrictions, the imposed distribution measures and the impossibility for the manufacturer to continue his business without interruption, the vis maior defence was sustained. ${ }^{55}$

\section{FROM SUBJECTIVE IMPOSSIBILITY TO UNFORESEEN CIRCUMSTANCES}

\section{A Shift in the Legal Debate}

The outbreak of the Great War fuelled a particular legal debate which had been smouldering for some time since the early 1900s, namely whether the concept of impossibility included both factual (objective) and personal (subjective) impossibility. The latter concept was potentially more debtor-friendly and implied that the debtor was excused for nonperformance if he had done everything reasonably within his powers to perform the contract but failed due to externalities for which he bore no responsibility. Coincidentally, the 1914 annual meeting of the Dutch Lawyers Association (Nederlandsche Juristenvereeniging, NJV) had been devoted to the legal consequences of employee strikes and industrial action. With regard to interference with performance of contracts, the majority of members voted in favour of a rule allowing a debtor to invoke the 'subjective force majeure doctrine' ${ }^{56}$

\footnotetext{
${ }^{53}$ Gerechtshof Arnhem, 25 March 1919, NJ 1919, 535 (Vd Werff en Geldersche Credietvereeniging Arnhem v Zweedsche Vennootschap Rederi Aktiebolaget Moeller \& Persson te Stockholm); Gerechtshof Amsterdam, 17 March 1922, W 1923, no 10992, 4.

${ }^{54}$ See eg Rechtbank Amsterdam, 21 February 1922, W 1922, no 10931, 3 (Firma Niehues \& Dütting v Van Kempen), holding that when entering into contract in August 1915, it was not foreseeable that the USA would join the war.

${ }^{55}$ Rechtbank Amsterdam, 27 February 1920, NJ 1920, 914 (Firma G Kroon \& Co v Nord Thomson exploitant van Nederlandsche Chemische Fabriek).

${ }^{56}$ See Scholten (n 43) 418. The 'subjective force majeure doctrine' was introduced in Dutch legal writing by JF Houwing, 'Overmacht of onmogelijkheid' [1904] Rechtsgeleerd Magazijn 250, 297. Cf Rutten (n 27 ) 247 ff.
} 
Some authors came to the conclusion that the war showed that the juxtaposition of objective and subjective impossibility was untenable, since possibility in commercial contracts (eg, for fungible goods) usually hinges on the extent of the debtor's willingness to dedicate resources to materialisation of the performance. ${ }^{57}$ Case law seemed to adhere to the subjective impossibility doctrine. ${ }^{58}$ The problem with this doctrine was that it did not offer a satisfactory explanation for the fact that impecuniosity did not constitute vis maior, that the debtor in a contract usually commits himself to a certain result (eg, the promise to deliver) and that foreseeable impossibility did not excuse the debtor.

It was only shortly after the Great War that the debate became more pronounced. ${ }^{59}$ In his 1919 doctoral thesis, JLL Wery explored the legal foundations for contractual liability and the basis of vis maior. He argued that, besides fault as a basis for ascribing responsibility for nonperformance, contractual risk was the proper basis for assigning responsibility. Therefore, personal conditions and circumstances could hardly ever constitute vis maior. ${ }^{60}$ In Wery's approach, emphasis was placed less on the distinction between possible and impossible (factual and legal) and more on the imputability of non-performance as such. It is posited here that the typology of war cases thus helped to shift the scholarly debate from semantics on what constitutes 'impossibility' to the openly normative approach of assignation of contractual responsibility. Such an open approach also offered a perspective for the introduction of a statutory provision on unforeseen circumstances. At the time, the Dutch Civil Code did not contain a specific provision concerning unforeseen circumstances, that is, the situation where due to some extraordinary unforeseen event after the conclusion of the contract performance is rendered far more onerous for at least one of the parties than anticipated. The shift to the openly normative approach of assignation of contractual responsibility made the introduction of such a provision come within reach. The 1923 doctoral thesis by Levenbach, which will be dealt with shortly, laid the foundations for a proper doctrinal discourse on exactly that issue.

For this to happen, however, the judiciary first had to warm to the idea that the 'good faith principle' encapsulated in Article 1374 DCC could be used to vary obligations in view of

\footnotetext{
${ }^{57}$ HMA Schadee, Overmacht (WL \& J Brusse's Uitgeversmaatij, 1915) 7.

${ }^{58}$ See Molengraaff (n 44) 12; EM Meijers, Behoort verandering in de feitelijke omstandigheden, waaronder een overeenkomst is gesloten, invloed te hebben op haar voortbestaan? Zoo ja, welke wettelijke regeling is te dien aanzien wenschelijk? (Preadvies Nederlandsche Juristen-Vereeniging 1918) (FJ Belinfante, 1918) 135 ff; MG Levenbach, lets over de spanning van de kontraktsband bij verandering in de omstandigheden (diss Amsterdam) (HJ Paris, 1923) $12 \mathrm{ff}$.

${ }^{59}$ S Royer, 'Pacta sunt servanda en de verandering van omstandigheden in het privaatrecht' [1972] RM Themis $514,522 \mathrm{ff}$.

${ }^{60}$ See Wery (n 39) $1 \mathrm{ff}$. Cf the book review S Van Brakel, 'JLL Wery, Overmacht bij overeenkomsten, Akad. Prft. Leiden, 1919-140 blz' [1920] Weekblad van het Regt 3, 3; G Kirberger, 'Overmacht bij Overeenkomsten (JLL Wery Akad Prft Leiden, 1919)' [1920] Rechtsgeleerd Magazijn 159.
} 
hardship. ${ }^{61}$ The question that divided opinion was whether the good faith principle merely related to the construction of agreed contractual obligations (spirit of the contract trumps the literal wording) or could also serve as a normative principle shaping the content of a contract. Although Article 1374 DCC contained a principle of good faith, at the time of the war it was applied rather restrictively. ${ }^{62}$ The Great War itself prompted the doctrinal debate on whether good faith could restrain or vary the obligations originally assumed by the parties. Until then, in case law the focus had been on impossibility and force majeure doctrines. After 1919, the emphasis in the lower courts slowly shifted to the good faith doctrine. ${ }^{63}$

Although in hindsight the Great War may indeed have had the function of 'warming' the courts to a comprehensive theory of 'good faith' in contract law, it did not appear to have done so at the time. Even as late as the 1920s, the Dutch Supreme Court (Hoge Raad der Nederlanden) attached more value to strict compliance with what was agreed than to what good faith might require from the parties in view of later events. In two landmark cases dating from 1926, the Supreme Court stuck to its guns and ruled that the 'good faith principle in the Civil Code does not authorise the court to amend, change, vary or neglect the essence of a contract in light of a change of circumstances' ${ }^{64}$ Both cases dealt with the problem of drastic changes to the price of raw materials and supplies during and after the war, which caused hardship for the contracting party that had undertaken to deliver at a price fixed in accordance with earlier price levels. The Supreme Court essentially ruled that the price agreed could not be amended or adjusted on the basis of the 'good faith' principle. These decisions met with scholarly hostility at the time. They proved ultimately untenable. Although the Supreme Court did in fact accept good faith as a principle of contract law in the 1920s, its scope remained limited and the court continued to resist attempts to amend or vary contracts on grounds of unforeseen circumstances until $1977 .^{65}$

Obviously, this is an ex post analysis of the contemporary debate. It took several more decades and the initiation of the restatement project of the New Dutch Civil Code after the Second World War for this debate to fully develop. It is argued here, however, that at the

\footnotetext{
${ }^{61}$ Art 1374 DCC provided: 'All legally made agreements bind those who entered into them as laws. They cannot be rescinded other than by mutual consent or by reasons deemed sufficient by statute. They shall be performed in good faith.'

${ }^{62}$ S Van Brakel, Leerboek van het Nederlandse Verbintenissenrecht, eerste deel (WEJ Tjeenk Willink, 1948) 466; Abas (n 39) 109, 126.

${ }^{63}$ See the overview by Abas ( $\mathrm{n}$ 39) 110.

${ }^{64}$ HR, 18 January 1926, NJ 1926, 203, WPNR 1926, no 2945, 270 (Stork v NV Haarlemsche Katoenmaatschappij (Sarong)); HR, 19 March 1926, NJ 1926, 441 (NV Textielfabriek 'Holland' v NV Tattersall \& Holdworth Machinefabrieken en Magazijnen 'De Globe' \& de Engelsche Vennootschap van Koophandel Butterworth \& Dickinson Ltd te Burnley, England). Cf HR, 9 February 1923, NJ 1923, 676, ruling that the good faith principle was predicated on the assumed will of the parties rather than some external normative yardstick.

${ }^{65}$ HR, 16 December 1977, NJ 1978, no 156 (Algemeen Ziekenfonds DPZ v X); HR, 27 April 1984, NJ 1984, no 679 (NVB v Helder).
} 
time of the Great War, there were early signs indicating that a shift in emphasis was on its way.

\section{Early Signs of Later Developments}

Although the Supreme Court resisted adjusting existing contractual rights, in the lower courts as well as in academic writing there were voices in favour of the acceptance of 'subjective impossibility' due to war conditions as a category of excusable non-performance. As mentioned above, in principle the debtor bore the risk of fluctuations in the cost of obtaining the (raw) materials needed to fulfil his obligation (unless a price variation clause was agreed). ${ }^{66}$ Lower court decisions during the war meandered; sometimes it was held that a price increase of 20-25 per cent was sufficient to argue vis maior, ${ }^{67}$ in others price increases of 25 per cent or even over 60 per cent did not justify the vis maior excuse. ${ }^{68}$ If, however, according to eminent scholars such as Meijers and Scholten, the fluctuation was of a systemic nature and threatened the livelihood of an entire class of debtors, legislative or judicial intervention was considered appropriate. ${ }^{69}$ In hindsight, the 1918 proceedings of the Dutch Lawyers' Association NJV sowed a seed that was to germinate at a later point in time. There Meijers presented his ideas on unforeseen circumstances. He later went on to extend these ideas, influenced by the German judicial approach to the 1920s devaluation crisis, into a draft for the new Dutch Civil Code. ${ }^{70}$ In turn, this draft influenced later Supreme Court decisions and thus marked the turning point for Dutch law. ${ }^{71}$

The other sign was the acceptance, at least by the legislature, that inability to pay can sometimes constitute excusable non-performance. Under peacetime conditions, debtors who owed a money debt could normally not argue impecuniosity as grounds for nonperformance. As long as there was money there was a possibility to pay, irrespective of whether the debtor actually had any money. ${ }^{72}$ War, however, may cause money to

\footnotetext{
${ }^{66}$ LE Visser, Behooren ten aanzien van de gehoudenheid tot nakoming eener verbintenis bijzondere regelen te gelden met betrekking tot werkstaking, en zoo ja, welke? (preadvies NJV) (Handelingen der Nederlandsche Juristen-Vereeniging, FJ Belinfante, 1914) 6 ff; Meijers (n 58) 175 ff; Wery (n 39) $131 \mathrm{ff}$.

${ }^{67}$ Rechtbank Den Bosch, 26 March 1915, NJ 1916, 439 (Firma H Van Roosmalen en Zoon v Firma Chr Fles); Gerechtshof Den Haag, 8 December 1916, W 10129 (Engel v Coöperative Inkoopsvereeniging van Roomsch Katholieke brood-, koek- en banketbakkerspatroons St Hubertus).

${ }^{68}$ Rechtbank Den Bosch, 26 March 1915, NJ 1916, 439 (Firma H Van Roosmalen en Zoon v Firma Chr Fles); Gerechtshof Amsterdam, 2 March 1917, W 10140 (NV Rhurorter Oelfabrik te Amsterdam v Habermehl te Nieuwveen).

${ }^{69}$ Meijers (n 58) 177; Scholten (n 43) 420; cf P Scholten, Verzamelde Geschriften (WEJ Tjeenk Willink, 1949) 40 $\mathrm{ff}$.

${ }^{70}$ See CJ Van Zeben, JW Du Pon and MM Olthof, Parlementaire Geschiedenis van het Nieuwe Burgerlijk Wetboek; Boek 6: Algemeen gedeelte van het verbintenissenrecht (Kluwer, 1981) $966 \mathrm{ff}$.

${ }^{71}$ HR, 16 December 1977, NJ 1978, no 156 (Algemeen Ziekenfonds DPZ v X); HR, 27 April 1984, NJ 1984, no 679 (NVB v Helder).

72 Rechtbank Almelo, 5 January 1916, NJ 1916, 1162 (Koudijs v Plaggemars).
} 
disappear, either factually or legally. ${ }^{73}$ As mentioned, the outbreak of the Great War brought the European money markets to a sudden halt. Most governments grappled with the issue of whether or not to introduce dedicated statutory emergency powers to impose moratoria on creditors and thus create breathing space for debtors who found themselves with unexpected liquidity problems due to the collapse of international and national trade and banking and were unable to meet their debts as a result. The Dutch government decided to introduce rather limited emergency legislation following the acute liquidity problems for some debtors. The resulting 1914 Postponement Act was not a proper moratorium affecting all contract debts. ${ }^{74}$ It merely allowed debtors who could substantiate that their inability to pay their pre-war debts was a consequence of war conditions to petition the court for a (renewable) six month moratorium. ${ }^{75}$ Likewise, debtors could petition for postponement of bankruptcy or attachment of assets. Interestingly, there are hardly any published court decisions in which the 1914 Act was invoked. This might in fact mean that the mere existence of the Act already made creditors more willing to voluntarily grant their debtors more time to perform. If that is indeed what happened, then the 1914 legislative intervention was an efficient instrument to tackle these unforeseen events. Although prompted by the emergency of the outbreak of war, the underlying rationale for such legislative intervention remained popular throughout the twentieth century. Arguably, this type of intervention made the concept of adjustment of existing contractual rights for reasons of change of circumstances more acceptable than it had been previously.

\section{Resistance versus Responsiveness}

That said, shortly after the Great War, the legislature was not willing to intervene more than it had done so far. On the occasion of the 1918 annual conference of the Dutch Lawyers' Association NJV, the members adopted the following resolution: 'the legislature shall adopt measures to clarify the legal consequences of the current world war on currently existing contracts.' The Ministry of Justice did not act on this resolution, much to the dismay of some lawyers who complained that practitioners needed guidance. ${ }^{76}$ Markets needed to sort themselves out in the post-war era.

\footnotetext{
73 On money payments during the war, see Rechtbank Breda, 26 June 1917, NJ 1917, 810 (Gerhardus und Söhne AG v Dierckx); Rechtbank Middelburg, 9 January 1918, W 1918, no 10220; Rechtbank Winschoten, 5 June 1918, NJ 1918, 1001; Rechtbank Utrecht, 27 February 1918, NJ 1918, 1048 (NV Utrechtse Bank v Eppinghausen).

74 'Uitwinningswet' or 'Uitstelwet', Act of 4 September 1914, Staatsblad 444. On the deliberations surrounding the 1914 Postponement Act, see MWF Treub, Oorlogstijd Herinneringen en indrukken (HD Tjeenk Willink \& Zoon, 1916) 258 ff.; IJ Brugmans, Paardenkracht en Mensenmacht (M Nijhoff, 1961), 435; Moeyes (n 1) 171.

${ }^{75}$ Cf. N De Beneditty, 'De Oorlog en de Huurovereenkomst' [1915] Weeklad voor Privaatrecht, Notariaat en Registratie (WPNR) 513, 513, who argued that the Act was also applicable to tenancy contracts.

${ }^{76}$ Th A Fruin in W 1919, no 10485, 4; MH Bregstein, 'Moet den rechter de bevoegdheid toekomen verbintenissen uit overeenkomst op bepaalde gronden zooals de goede trouw, te wijzigen? (Preadvies NJV 1936)' in Verzameld Werk (WEJ Tjeenk Willink, 1960) 200-1.
} 
It was not until the 1930s that the legislature embarked on a new wave of regulatory intervention in markets, mostly due to the disruptive economic crisis that emerged. ${ }^{77} \mathrm{By}$ contrast, in the 1920s and 1930s there were few signs that the Dutch Supreme Court was willing to allow courts to amend, vary or discharge contract obligations with reference to 'good faith' in view of unforeseen circumstances. In German and English law, at the moment of the outbreak of the Great War, the concept of frustration had already been developed, or at least discussed and contemplated. ${ }^{78}$ Dutch law did not have any such doctrine available at all, although some authors argued that the principle of contract performance in good faith could assume a comparable function. ${ }^{79}$ Although some supported the introduction of a statutory framework for dealing with material change of economic circumstances, postimpossibility duties and amendment of existing contracts, ${ }^{80}$ no general legislative intervention to address the unforeseen shifts in the balance between debtors and creditors took place in the Netherlands. ${ }^{81}$ And, as mentioned, courts were mostly unwilling to intervene on their own account and the Supreme Court resisted calls for innovation. ${ }^{82}$ The Great War did, however, fuel the scholarly debate and the development of proper good faith theories for amendment and variation of contracts in cases of unforeseen circumstances. Moreover, the German 1920s devaluation of the Mark and the economic crisis of the 1930s prompted academics to take a less rigid approach to the subject. ${ }^{83}$ In 1931, however, the Dutch Supreme Court ruled that a money debt expressed in German currency was to be paid in nominal value and that unforeseen circumstances such as hyperinflation as such could not

\footnotetext{
77 See Schuldbrievenwet 1934 (Debentures Act 1934), the Crisis-Hypotheekaflossingswet 1936 (Crisis Mortgage Payment Act 1936) and the Crisispachtwet 1932 (Crisis Land Lease Act 1932).

${ }^{78}$ A Thier, 'Legal History' in E Hondius and HC Grigoleit (eds), Unexpected Circumstances in European Contract Law (Cambridge University Press, 2011) $27 \mathrm{ff}$. For an in-depth review of the development of English law, see the contribution by Catharine MacMillan to this issue; cf J Oosterhuis, 'Unexpected Circumstances Arising from Word War I and Its Aftermath: 'Open' Versus 'Closed' Legal Systems' (2014) 7 Erasmus Law Review (forthcoming). On the development of German law, also prior to Oertmann's seminal 1921 work Die Geschäftsgrundlage. Ein neuer Rechtsbegriff, see R Meyer-Pritzl, '§§ 313-314. Störung der Geschäftsgrundlage. Kündigung von Dauerschuldverhältnissen aus wichtigem Grund' in M Schmoeckel, J Rückert and $R$ Zimmermann (eds), Historisch-kritischer Kommentar zum BGB-Band II/2 Schuldrecht:Allgemeiner Teil; 2 Teilband (Mohr Siebeck, 2007) $1708 \mathrm{ff}$.

${ }^{79}$ TA Fruin, Behoort verandering in de feitelijke omstandigheden, waaronder eene overeenkomst is gesloten, invloed te hebben op haar voortbestaan? (Preadvies Nederlandsche Juristen-Vereeniging 1918) (FJ Belinfante, 1918) 46.

${ }^{80}$ H Verkouteren, 'Oorlogscontracten' [1921] Weekblad van het Recht 4; Levenbach (n 58); cf Abas (n 39) 129 ff.

${ }^{81}$ There were supportive references to the Belgian 1919 Act (eg Weekblad van het Recht no 10485 (1919), 4) but to no avail.

${ }^{82}$ Contrast the legal development in German courts; see eg JP Dawson, 'Effects of Inflation on Private Contracts: Germany, 1914-1924' (1934) 33 Michigan Law Review 171, 178 ff.

${ }^{83}$ eg MH Bregstein, 'Moet den rechter de bevoegdheid toekomen verbintenissen uit overeenkomst op bepaalde gronden, zooals de goede trouw, te wijzigen? Zoo ja, in welke gevallen en in hoeverre (preadvies NJV 1936)' in Verzameld werk (1960) (WEJ Tjeenk Willink, 1936) $200 \mathrm{ff.}$
} 
authorise courts with reference to 'good faith' to increase money debts. ${ }^{84}$ In response to this decision, academics argued that courts should be authorised to amend contract debts in view of extraordinary currency changes. ${ }^{85}$ Others argued that the whole idea of international exchange rates is that they fluctuate and that, certainly in a national context, issues such as hyperinflation which are disruptive to society as a whole should be solved by comprehensive legislative rather than piecemeal judicial intervention. ${ }^{86}$ Lower courts did not always follow the Supreme Court's conservative lead. Sometimes, they took a more responsive stance and they simply cloaked 'unforeseen circumstances' as impossibility. ${ }^{87}$ Some even openly accepted a doctrine of unforeseen circumstances. ${ }^{88}$

\section{THE NEUTRALITY OF CONTRACT LAW}

In some ways, one can consider Dutch contract law during the Great War in terms of its role as an instrument of neutrality. Earlier, we saw that the Dutch government made clever use of a purely self-regulatory contract scheme administrated by the NOT as a means of implementing the Dutch neutrality doctrine. It can be argued that the reticence of the Dutch courts to allow defences concerning 'impossibility' and vis maior may also be gauged in neutrality terms: whoever came to court, irrespective of nationality, would be held to perform in accordance with his promises. Consider, for instance, the effect of foreign nations' restrictions on payments to enemies. Here, the Dutch courts applied a policy which was perfectly in line with the Dutch neutrality doctrine but which also killed any burgeoning concept of 'good faith' as an instrument of contract adaptation or variation. In one particular case, a German seller agreed in the spring of 1914 to deliver to an English buyer in the Rotterdam harbour payment against delivery. ${ }^{89}$ However, when the seller delivered shortly after the outbreak of the war, the buyer refused to pay. He argued that the English Trading with the Enemy Proclamation no 2 (dated 9 September 1914) rendered payment impossible

\footnotetext{
${ }^{84}$ HR, 2 January 1931, NJ 1931, 274. The decision was criticised forcefully by, eg, Meijers in his case note (NJ 1931, 281) and Levenbach (n 58) $200 \mathrm{ff}$.

${ }^{85}$ eg Meijers in his case note NJ 1931, 281; Levenbach (n 58) $200 \mathrm{ff}$.

${ }^{86}$ Cf AS Hartkamp and CH Sieburgh, Verbintenissenrecht: Algemeen overeenkomstenrecht (Deel 6-III van Mr C Assers handleiding tot de beoefening van het Nederlands Burgerlijk Recht) (Kluwer, 13th edn 2010) no 450-51, building on (but also extending the arguments by) LEH Rutten, Mr C Asser's Handleiding tot de beoefening van het Nederlandsch Burgerlijk Recht-Derde deel-Verbintenissenrecht-Tweede stuk-De overeenkomst en de verbintenis uit de wet (WEJ Tjeenk Willink, 2nd edn 1961) 274-5.

${ }^{87}$ Gerechtshof Amsterdam, 11 January 1922, W 1922, no 10904, 1 (NV Hollandia v Firma HC van Hulsteijn \& Zoon): 'a defence of force majeure may be justified when [the seller] cannot perform due to an unforeseen circumstance, without financial sacrifice which cannot reasonably be asked from him.'

${ }^{88}$ See eg Rechtbank Utrecht, 14 March 1916, W 10117 (Kommanditgesellschaft onder firma Geybotle en Cie, Zwickau v Revermann, Utrecht); Gerechtshof Den Bosch, 30 November 1920, W 1921, no 10667, 2, NJ 1921, 151 (NV Weerter Scheepsbouw Maatschappij v H Damen).

${ }^{89}$ Rechtbank Rotterdam, 17 December 1915, W 1916, no 9898, 2-3, NJ 1916, 434; Gerechtshof Den Haag, 24 November 1916, W 1917, no 10060, 2, NJ 1917, 279, WPNR 1917, no 2466, 159; HR, 2 November 1917, NJ 1917, 1136, WPNR 1917, no 2500, 572 (Henkel \& Co, Düsseldorf v Brice Whyte \& Sons Ltd, Glasgow/Liverpool).
} 
for him - he would face the risk of prosecution in England if he were to pay. The Dutch Supreme Court held:

[Considering] that the respondent [ie, the claimant at first instance, $\mathrm{WvB}$ ] has requested an injunction for performance of a contract, which was to be executed in the Netherlands and governed by Dutch law, while the claimant, who relies on force majeure obstructing performance of her obligations in this country, as such exclusively relies on a prohibition laid down in English law, basing her defence on a moral duty which is said to compel her to obey that prohibition and on the unpleasant consequences she fears the non-compliance with that prohibition will have for her;

C[onsidering] however that the provision of a foreign statute shall not impede justice from running its course in this country, and that reference to the consequences in order to escape compliance with a legal duty by a party who knew this duty was subject to Dutch law in all its consequences, is without effect ...90

Thus, the judicial application of contract law during and after the Great War converged with the Dutch neutrality doctrine. So, when in 1931 the Dutch Supreme Court ruled that the nominalism principle remained applicable to money debts expressed in German currency and that unforeseen circumstances such as German hyperinflation did not authorise Dutch courts to amend claims with reference to 'good faith', ${ }^{11}$ it may have done more than just display a conservative and non-interventionist judicial stance. Indeed, one could speculate that the ramifications for the Dutch neutrality doctrine themselves may have made Dutch courts reluctant to intervene in contracts for reasons of 'unforeseen circumstances'.

\section{FINAL REFLECTIONS}

In Europe, the Great War ended the long nineteenth century of laissez faire economic policies. ${ }^{92}$ In the Netherlands as elsewhere, the War necessitated government interventions in various markets and this heralded a new era of regulatory involvement in the fair operation of markets. Having witnessed the chaos, uncertainty, shortages, suffering and upheaval caused by the war, the Dutch legislature would never return to the pre-war state of liberal economic thinking. ${ }^{93}$ As such, this indubitably meant that private law doctrines, notably freedom of contract, were to play a different and less pronounced role in certain

\footnotetext{
${ }^{90}$ HR, 2 November 1917, NJ 1917, 1136, WPNR 1917, no 2500, 572 (Henkel \& Co, Düsseldorf v Brice Whyte \& Sons Ltd, Glasgow/Liverpool).

${ }^{91}$ HR, 2 January 1931, NJ 1931, 274.

${ }^{92}$ G Hardach, The First World War 1914-1918 (Allen Lane, 1977) 283 ff; R Findlay and KH O'Rourke, Power and Plenty: Trade, War, and the World Economy in the Second Millennium (Princeton University Press, 2007$) 429$.

${ }^{93}$ Kruizinga (n 1) 305. Cf C Jansen, 'De Impact van de Eerste Wereldoorlog op het Nederlandse privaatrecht' [2014] Nederlands Juristenblad 1491, 1499.
} 
markets. ${ }^{94}$ But did the war also lead to significant changes in the substance of private law doctrines? The answer to that question is less straightforward. Change in private law is difficult to measure, especially if such change is considered to be brought about incrementally by cases and court decisions. Moreover, any claim of causality between legal change and historical and social phenomena needs to be made with the utmost caution. ${ }^{95}$ Therefore, I have not made a case for conceptualising the Great War as the turning point in the recent history of Dutch contract law. What I have shown, however, is that the Great War was the first intensive test of the contract law framework of the 1838 Civil Code. To my mind, this test showed that the conceptual structure of impossibility and vis maior was flawed: the judicial application of these concepts brought to light the fact that impossibility is not identical to vis maior, nor is it a necessary condition for vis maior. Thus, the courts felt compelled to bend these two statutory concepts to evaluate subjective impossibility as a potential excuse for non-performance. The war conditions also showed that the courts were extremely unwilling to let debtors off the hook easily, that the vis maior defence was more often rejected than sustained, and that the Supreme Court long resisted attempts to jeopardise the 'neutrality of private law'. In this sense, the Dutch courts were predictable and firm enforcers of promises. Interestingly enough, they were also trying, or so it appears, to emulate the Dutch neutrality doctrine through their contract law decisions.

In terms of the marks left by the Great War on Dutch legal scholarship, two influential postwar monographs stand out. Wery's book on vis maior benefited from pre-war work by others but it offered an outline for the future development of 'imputable and non-imputable non-performance' as an alternative model for dealing with vis maior. As such, it signified a move away from the malleable concept of 'impossibility' towards a more transparent approach of assigning responsibility. The 1923 monograph by Levenbach on the disruption of the contractual synallagma fuelled the debate on unforeseen circumstances as a separate doctrine of contract law. ${ }^{96}$ Although the Supreme Court was late in acknowledging good faith as the engine for the introduction of such an innovation in contract law, it was clear after the Great War that several lower courts and academics were convinced that this was indeed the right path. It was not until well after the Second World War that the Supreme Court proved them right.

\footnotetext{
${ }^{94}$ Cf SR Eiffler, 'Die 'Feuertaufe' des BGB: Das Vertragsrecht des Bürgerlichen Gesetzbuchs und das Kriegswirtschaftsrecht des 1. Weltkriegs' (1998) 20 Zeitschrift fur Neuere Rechtsgeschichte 238, 239.

${ }^{95}$ On statements of causality in (legal) history, see eg RJ Evans, In Defence of History (Granta, 2000) $129 \mathrm{ff} ; \mathrm{N}$ Ferguson (ed), Virtual History (Picador, 1997).

${ }^{96}$ Levenbach (n 58) $12 \mathrm{ff}$.
} 